\title{
Diel feeding activity and intensity in the European eel Anguilla anguilla (L.) during an annual cycle in a Cantabrian stream
}

\author{
S. Costa-Dias ${ }^{(1,2,3)}$, J. Lobón-Cerviá( ${ }^{(3)}$ \\ Received September 8, 2008 / Reçu le 8 septembre 2008 \\ Accepted November 28, 2008 / Accepté le 28 novembre 2008
}

\section{ABSTRACT}

Key-words: Diel and seasonal shifts in the feeding activity and intensity of a riverine anguilla, feeding intensity, diel activity, riverine stock stock of European eels, Anguilla anguilla (L.), were assessed in the Río LLorín, a right-side tributary of the Río Esva drainage (northwestern Spain). No consistent diel cycles were detected in either season (eels feed with similar intensity in the day and at night), but increased feeding activity was evidenced during the warmer months relative to weaker but still significant activity in winter. Heterogeneity in both feeding activity and intensity may stem from the high rates of secondary production in the form of benthic food available for eels, and mild temperatures all year round.

\section{RÉSUMÉ}

Activité et intensité journalières de l'alimentation de l'anguille européenne Anguilla anguilla (L.) durant un cycle annuel dans une rivière cantabrique

Mots-clés : anguille, intensité de l'alimentation, activité journalière, population
Les variations journalières et saisonnières de l'activité et de l'intensité de l'alimentation d'une population d'anguilles européennes Anguilla anguilla (L.) ont été étudiées dans le Río LLorín, un affluent rive droite du Río Esva (Nord-Ouest de l'Espagne). Aucun cycle journalier n'a été détecté au cours de l'année (les anguilles se nourrissent avec la même intensité de jour comme de nuit), mais une augmentation relative de l'activité alimentaire pendant les mois plus chauds est mise en évidence comparée à l'activité plus faible en hiver. Les variations de l'activité et de l'intensité de l'alimentation peuvent provenir de la forte production de nourriture benthique disponible pour les anguilles et des températures clémentes toute l'année.

\section{INTRODUCTION}

In the course of its life cycle, the European eel, Anguilla anguilla (L.), spends a variable but significant period in freshwaters that may range from 3 (males) to 20 (females) years (Vøllestad, 1992). Although not without exception (eels may remain in brackish waters, Vøllestad, 1986), a development period is accomplished in rivers before maturation, energy acquisition being the main purpose of this period.

(1) CIMAR/CIIMAR, Centro Interdisciplinar de Investigação Marinha e Ambiental, Universidade do Porto, Rua dos Bragas 289, 4050-123 Porto, Portugal, sergiacd@ciimar.up.pt

(2) ICBAS - Instituto de Ciências Biomédicas de Abel Salazar Universidade do Porto, Lg. Prof. Abel Salazar 2, 4099-003 Porto, Portugal

(3) Dep. Ecología Evolutiva, Museo Nacional de Ciencias Naturales (CSIC), C/ José Gutiérrez Abascal 2, 28006 Madrid, Spain 
The European eel has been described as omnivorous and its feeding habits have been assessed in a diversity of habitats including estuaries (Moriarty, 1987; Costa et al., 1992), streams and rivers (Sinha, 1969; Rasmussen and Therkildsen, 1979; Callaghan and McCarthy, 1994; Lara, 1994; Cullen and McCarthy, 2007), and lakes (De Nie, 1982; Moriarty, 1987; Bergersen and Klemetsen, 1988; Clarke et al., 1993). The few studies dealing with die and seasonal patterns of feeding activity and intensity have reported increased activity with increased temperature (Tesch, 2003) and nocturnal feeding (Lecomte-Finiger, 1983; Clarke et al., 1993; Tesch, 2003) with increased intensity at dawn and at dusk.

To further investigate this issue we analysed feeding activity and intensity in a stock of eels inhabiting a tributary of the Río Esva where eel is accompanied by brown trout (Salmo trutta L.) and Atlantic salmon (Salmo salar L.). Previous studies on the feeding ecology of these two salmonids in the Río Esva reported continuous day and night feeding patterns the year round (Rincón, 1993; Utrilla, 1997). The present study examines whether patterns of diel feeding activity and intensity of European eels track similar patterns to those exhibited by salmonids in Río Esva tributaries.

\section{MATERIAL AND METHODS}

\section{> STUDY AREA}

The Río LLorín is a right-side tributary of the Río Esva drainage (Asturias, northwestern Spain), located about $11 \mathrm{~km}$ upstream of the Esva mouth into the Cantabrian Sea. The Río LLorín flows over siliceous (quarzite) bedrock and its stony substratum is composed of sand (10\%), gravel (50\%), pebble (30\%) and stones (10\%). The Río LLorín is essentially fed by rain and run-off, and discharge fluctuates seasonally depending on rainy conditions. Overall, rainfall increases in spring and autumn but episodic or persistent rainfall may occur during prolonged time periods. Consistent with the mild climatic conditions that typify the coastal Cantabrian region, the stream temperatures are mild all year round, with winter stream temperatures that seldom reach the freezing level and summer temperatures with maxima at $20^{\circ} \mathrm{C}$ (Lobón-Cerviá and Rincón, 1998).

\section{> SAMPLING STRATEGY}

Eels were collected monthly from August 1990 to July 1991 (except February and September) by electrofishing in a 1-km-long stream section (average width $=10 \mathrm{~m}$ and depth $=30 \mathrm{~cm}$ ). Sampling started at the lowermost stream reach and collections of $\sim 10$ individuals were made every three hours until the completion of a 24 -hour daily cycle. During the following month, sampling was conducted by commencing the eel sampling just above the upper limit of the site previously sampled. Overall, we attempted to maintain a constant 30-minute fishing effort and attempted to collect 10 individuals every time period during the diel cycle. As a whole, we collected and analysed an average of 74 eels in each monthly sample, which amounted to a total of 735 eels, of which 413 were actively feeding (with stomach content) and they were used for subsequent analysis of feeding intensity. Stream water temperatures $\left({ }^{\circ} \mathrm{C}\right)$ were recorded at every sampling occasion (i.e., 8 temperature records per day).

To prevent digestion, eels were ice-preserved during transport to the laboratory where they were frozen and stored until analysis. Individual total weight $(0.01 \mathrm{~g})$ was obtained prior to dissection and stomach contents were removed and weighed to $0.0001 \mathrm{~g}$.

\section{> DATA ANALYSIS}

All individuals collected were in the range $10-34 \mathrm{~cm}$. As a consequence, we focused our analysis on all individuals with no separation of size or age class. Feeding activity and intensity were quantified as follows: 
(1) Feeding activity $\left(A_{l}\right)$ was considered as the number of individuals with food in their guts (Ni) relative to the total number of individuals collected in each sample $\left(\mathrm{N}_{T}\right)$ and was quantified as:

$$
A_{I}=100 *\left(N i / N_{T}\right) .
$$

(2) Feeding intensity $\left(l_{1}\right)$ was considered to be reflected by the amount of food in the gut and was quantified for each single individual as the weight of food in the gut (Wi) relative to the total weight of the individual $\left(\mathrm{W}_{\mathrm{T}}\right)$ :

$$
\mathrm{I}_{\mathrm{I}}=100 *\left(\mathrm{Wi} / \mathrm{W}_{\mathrm{T}}\right) \text {. }
$$

Analysis of variance (Zar, 1999) was used to explore the effects of the month and time of day (hour) on both feeding activity $\left(A_{l}\right)$ and intensity $\left(l_{I}\right)$.

\section{RESULTS}

Stream water temperatures at the time of sampling (Figure 1) revealed a seasonal thermal regime typical of coastal Cantabrian streams: mild summers with temperatures around $15-16{ }^{\circ} \mathrm{C}$ in July and August were followed by mild winters with the lowest temperatures in December and January attaining, on average, $\sim 6^{\circ} \mathrm{C}$.

Active eels were recorded across the whole range of temperatures and months with no obvious period of quiescence in evidence (Figure 2). However, both feeding activity and intensity varied somewhat across months. An ANOVA for the feeding activity quantified with the index $A_{l}$ (Table IA) revealed significantly lower numbers of feeding eels in October $(33.7 \%$ of the individuals) and during the winter months (December, January and March; $~ 44.5 \%$ of the individuals). Markedly higher numbers were recorded in spring and summer including April, May, June and July (66.0 to $77.3 \%$ ). However, as revealed by the non-significant effect of the time of day (Table IA), no consistent pattern in diel activity was evidenced and a new ANOVA for the combined hours of daylight versus night also revealed a non-significant effect $\left(F_{1,9}=0.07, P=0.79\right)$.

Likewise, an ANOVA for the feeding intensity, quantified with the index $I_{I}$ (Figure 3), showed a significant effect of the month but a non-significant effect of the time of day (Table IB), and a new ANOVA for the effects of the time of day for each single month separately also revealed a non-significant effect (Table II). Thus, feeding intensity varied around a mean value $\mathrm{I}_{\mathrm{I}}=1.1 \%$, with the highest means in May (1.49\%), June (1.22\%) and November (1.38\%) and the lowest in March (0.65\%) and October (0.76\%).

As a consequence, the number of eels feeding actively increased in the warmer months but the relative numbers of eels feeding during the day and night remained similar across months. Both feeding activity and intensity described a consistent seasonal pattern with higher numbers of individuals feeding more intensively in the warmer months and decreased numbers in winter (Figure 4). The only exception to this seasonal pattern was November when slightly decreased temperatures (i.e., $\sim 9.4^{\circ} \mathrm{C}$ ) were associated with a high percentage of actively feeding individuals (69.7\%).

\section{DISCUSSION}

This study shows that, in the Río LLorín, a typical coastal stream of the Cantabrian corridor of northwestern Spain that is fully occupied by eels, and where the temperature regime is rather mild with no high or low temperature extremes, the eels remain active the year round, showing only slight differences in their feeding activity and intensity across months and no obvious diel pattern, with apparently similar amounts of individuals feeding during the day 


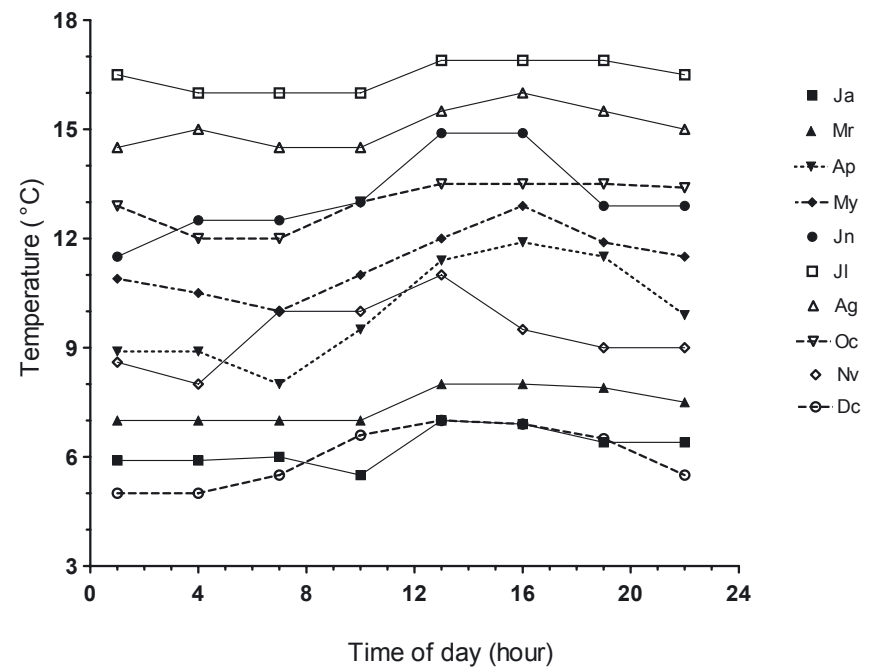

\section{Figure 1}

Stream water temperatures $\left({ }^{\circ} \mathrm{C}\right)$ recorded at the time of sampling in the Río LLorin over the sampling months.

Figure 1

Température de l'eau $\left({ }^{\circ} \mathrm{C}\right)$ mesurée dans le Río LLorín au moment des pêches pendant l'année d'échantillonnage.
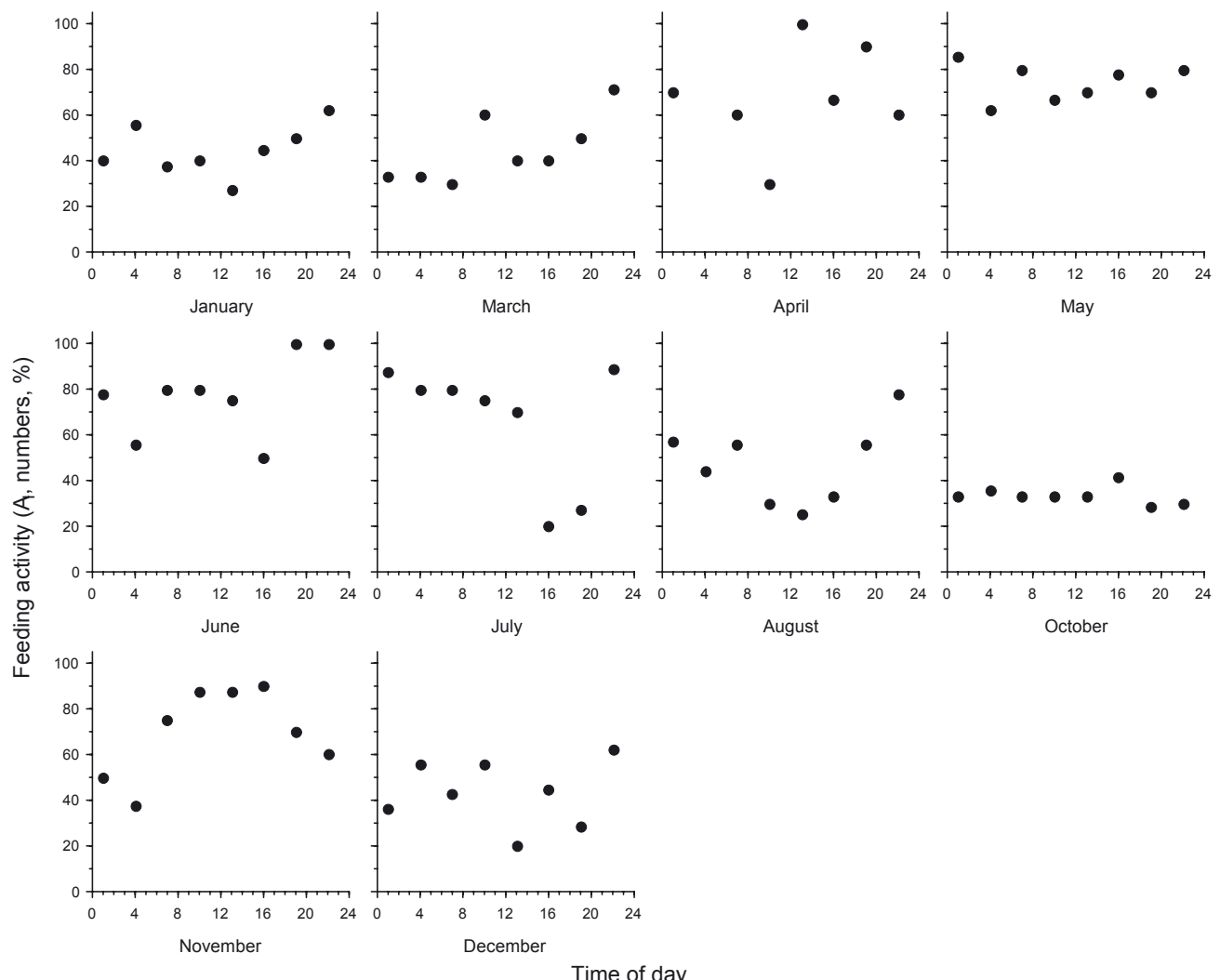

\section{Figure 2}

Feeding activity as quantified with the index ( $A_{\text {, }}$, the percent of individuals with gut content) in every sample (time of day) over the study months.

\section{Figure 2}

Activité alimentaire quantifiée par l'indice $\left(A_{l}\right.$, pourcentage d'individus avec un estomac rempli) à chaque échantillon (heure de la pêche) au cours des mois d'étude. 


\section{Table I}

Results of ANOVA (F-values and $P$, significance level) for the effects of the month (10) and time of day (8) on (A) the feeding activity quantified with the index $A_{1}$ and $(B)$ the feeding intensity quantified with the index I, for the eels Anguilla anguilla (L.) of the Río LLorin (Asturias, northwestern Spain). Note that the first ANOVA is based on the total number of individuals pooled (Figure 2), whereas the second ANOVA is based on the analysis of single individuals (Figure 3). df are the degrees of freedom and $V \%$ is the amount of variance explained (in percent) by each effect.

\section{Tableau I}

Résultats des ANOVA (valeurs de $F$ et $P$, niveau de significativité), pour les effets mois (10) et heure du jour (8) sur (A) l'activité alimentaire quantifiée par l'indice $A_{1}$ et (B) l'intensité alimentaire quantifiée par l'indice I, pour les anguilles Anguilla anguilla (L.) du Río LLorín (Asturies, Nord-Ouest de l'Espagne). À noter que la première ANOVA est calculée sur le nombre total d'individus (Figure 2) alors que la seconde ANOVA est faite sur les valeurs individuelles (Figure 3). df sont les degrés de liberté et V\% est la part de la variance expliquée (en pourcentage) par chaque effet.

\begin{tabular}{|l|c|c|c|c|}
\hline (A) & df & $F$ & $P$ & V\% \\
\hline Month (M) & 9 & 6.90 & $<0.001$ & 47.1 \\
\hline Time of day (TD) & 7 & 1.09 & 0.377 & 5.8 \\
\hline $\mathbf{M}^{\star}$ TD & 62 & & & 47.1 \\
\hline \multicolumn{5}{|l|}{} \\
\hline (B) & df & $F$ & $P$ & V\% \\
\hline Month (M) & 9 & 3.11 & 0.001 & 6.5 \\
\hline Time of day (TD) & 7 & 0.76 & 0.621 & 1.2 \\
\hline M*TD & 62 & 0.96 & 0.569 & 13.9 \\
\hline Error & & & & 78.3 \\
\hline
\end{tabular}

and night throughout the year. Although no consistent diel cycles were detected in either season, increased feeding activity and intensity were evidenced in the warmer months.

The notion that European eels are active and feed intensively during late spring and summer and become inactive and cease feeding in autumn and winter has been reported for a number of European regions including Wales (Thomas, 1962; Sinha and Jones, 1967), Ireland (Moriarty, 1982; Cullen and McCarthy, 2007), Scotland (Hussein, 1981), France (Lecomte-Finiger, 1983), Denmark (Rasmussen and Therkildsen, 1979), the Netherlands (De Nie, 1987), and temperate Europe (Tesch, 2003). Moreover, Lecomte-Finiger (1983) described diel feeding patterns with a predominance of nocturnal feeding activity in spring and summer. Clearly, none of those patterns match the patterns elucidated for the studied Cantabrian stock. However, discrepancies may be simply caused by the different thermal regimes in northern and central Europe watercourses relative to Cantabrian coastal streams. Eel activity has been suggested to be temperature-dependent (Tesch, 2003). This being the case, a temporally persistent feeding activity in the Cantabrian eels may be caused by the combined effects of mild temperatures and high rates of secondary production (Rincón and Lobón-Cerviá, 1997). Warmer temperatures and abundant food available across seasons may permit eels not only to be active but also feed the year round. Heterogeneity in both feeding activity and intensity may stem from the combined effects of high rates of secondary production in the form of benthic food available for eels all year round, and mild winters.

Nevertheless, a study conducted in the Río Nivelle (Neveu, 1981), a small French river located at a similar latitude to the Río Esva, showed a similar pattern of feeding activity. 


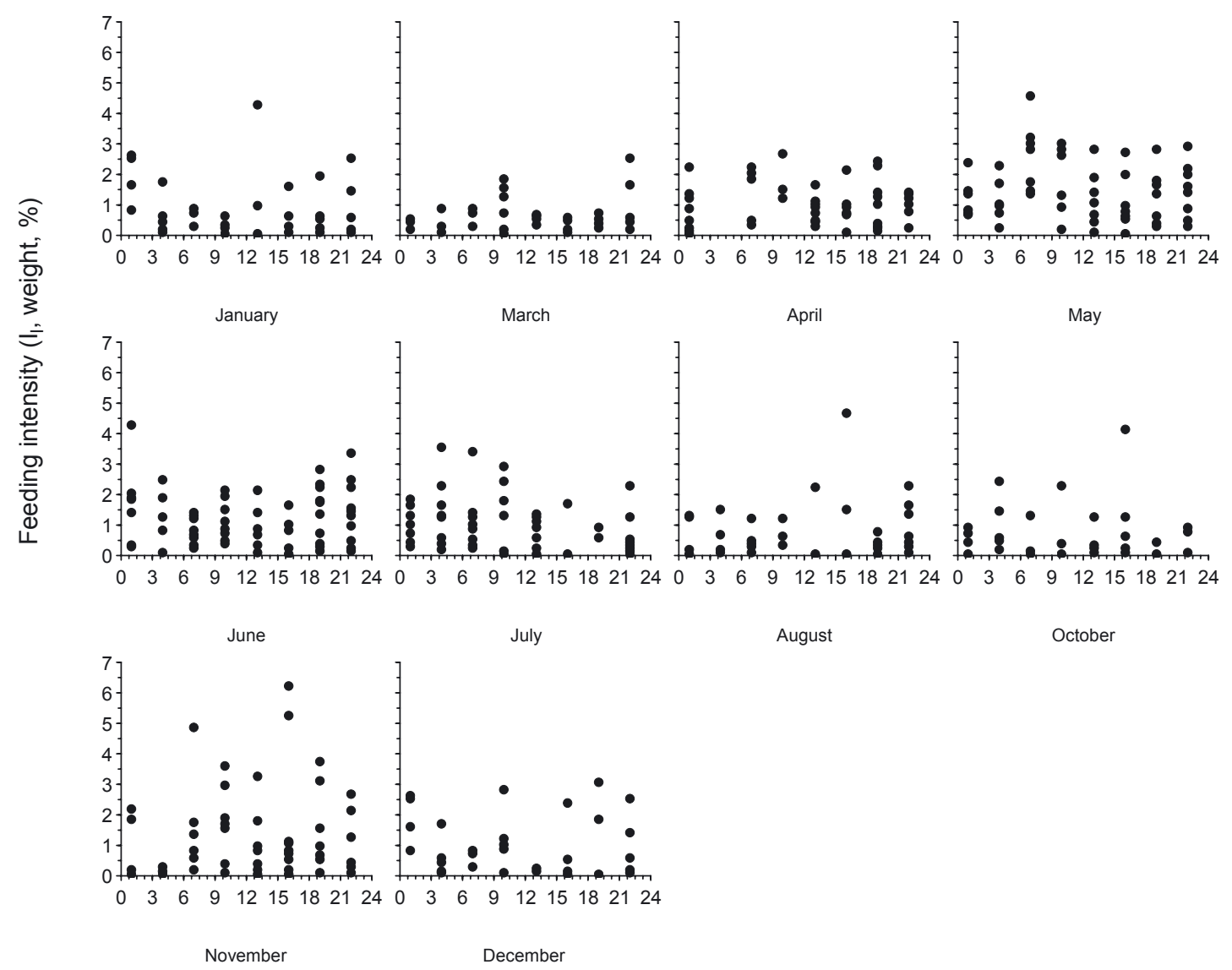

Time of day

\section{Figure 3}

Feeding intensity index (I) for every sample (time of day) over the study months. Each point represents one single individual.

\section{Figure 3}

Indice de l'intensité alimentaire $\left(l_{1}\right)$ pour chaque échantillon (heure de la pêche) au cours des mois d'étude. Chaque point représente un seul individu.

In that study, the author also questions the latitudinal factor and the possible influence of mild temperatures. The conclusions, however, were based on a single daily cycle in June with samples collected every $6 \mathrm{~h}$. Neveu (1981) reported that, in June, smaller eels $(<30 \mathrm{~cm})$ showed continuous feeding, while larger individuals $(>30 \mathrm{~cm}$ ) exhibited nocturnal feeding activity. The practical non-occurrence of eels $>30 \mathrm{~cm}$ in the Río Esva precludes further comparisons (Lobón-Cerviá et al., 1995).

Nevertheless, despite substantial differences in the temporal patterns of feeding among stocks across the European distributional range, the values of the feeding intensity index appear similar to those reported by Lecomte-Finiger (1983). Lower values of the feeding intensity index in the Río LLorín can be expected because, according to studies on prey items of eel in streams of the Río Esva drainage (Rincón and Lobón-Cerviá, 1997), these are mainly small-sized insects.

Interestingly, the feeding patterns of the European eel in the Río Esva are quite similar to those described for the accompanying salmonids, Atlantic salmon (Utrilla, 1997) and brown trout (Rincón, 1993). Consistency among the patterns allows us to hypothesise that 
Table II

Results of ANOVA for the effects of the time of day (8) on the feeding intensity quantified with the index I, for each single month. $N$ is the number of individuals and other symbols as in Table I. Note that no instance was significant.

\section{Tableau II}

Résultats de l'ANOVA pour les effets heure du jour (8) et intensité de l'alimentation quantifiée par l'indice I, calculée pour chaque mois. $N$ est le nombre d'individus, les autres symboles sont les mêmes qu'au tableau I. À noter qu'aucun effet n'est significatif.

\begin{tabular}{|l|c|c|c|c|c|}
\hline & $N$ & df & $F$ & $P$ & V\% \\
\hline January & 33 & 7 & 1.43 & 0.238 & 28.6 \\
\hline March & 32 & 7 & 1.06 & 0.417 & 23.6 \\
\hline April & 45 & 6 & 1.02 & 0.426 & 13.9 \\
\hline May & 54 & 7 & 1.96 & 0.081 & 23.0 \\
\hline June & 59 & 7 & 0.97 & 0.464 & 11.7 \\
\hline July & 48 & 7 & 0.70 & 0.673 & 10.9 \\
\hline August & 33 & 7 & 1.14 & 0.373 & 24.1 \\
\hline October & 29 & 7 & 0.45 & 0.857 & 13.1 \\
\hline November & 49 & 7 & 0.53 & 0.804 & 8.4 \\
\hline December & 31 & 7 & 1.22 & 0.334 & 27.0 \\
\hline
\end{tabular}
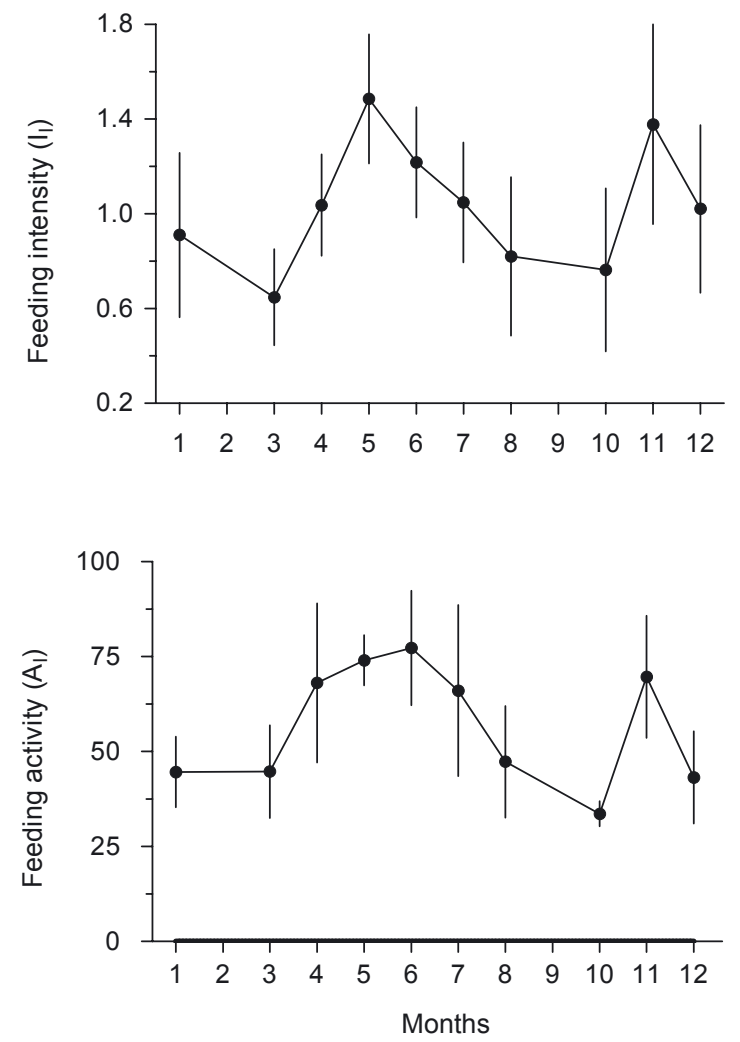

\section{Figure 4}

Mean $( \pm 95 \% C L)$ monthly feeding activity and intensity as quantified by the indexes $A_{l}$ and $I_{l}$, respectively, over the study months.

\section{Figure 4}

Moyenne ( $\pm 95 \% \mathrm{CL}$ ) mensuelle de l'activité et de l'intensité alimentaires quantifiées respectivement par les indices $A_{l}$ et $I_{l}$, pendant les mois d'étude. 
the underlying environmental factors related to mild temperatures operate similarly on the three co-occurring species in this geographical region.

\section{ACKNOWLEDGEMENTS}

These data were collected as a part of the long-term studies of the Río Esva fish populations. Administrative permissions for fish were obtained by agreement between the CSIC and Principado de Asturias. The senior author, Sérgia Costa Dias, acknowledges the Portuguese Foundation for Science and Technology (FCT) for financial support through a Ph.D. grant (SFRH/BD/16922/2004).

\section{REFERENCES}

Bergersen R. and Klemetsen A., 1988. Freshwater eel Anguilla anguilla (L.) from North Norway, with emphasis on occurrence, food, age and downstream migration. Nordic J. Fresw. Res., 64, 54-66.

Callaghan R.M. and McCarthy T.K., 1994. The food and feeding of eels (Anguilla anguilla L.) in an Irish river system, EIFAC Working Party on Eel, Oviedo, Spain.

Clarke D.A., McCarthy T.K. and Cowx I., 1993. Foraging activity patterns and diets of yellow eels Anguilla anguilla (L.) in Lough Derg, EIFAC 8th Session, Olsztyn, Poland.

Costa J.L., Assis C.A., Almeida P.R., Moreira F.M. and Costa M.J., 1992. On the food of the European eel, Anguilla anguilla (L.), in the upper zone of the Tagus estuary, Portugal. J. Fish Biol., 41, 841-850.

Cullen P. and McCarthy T.K., 2007. Eels (Anguilla anguilla (L.)) of the lower River Shannon, with particular reference to seasonality in their activity and feeding ecology. Biology and Environment: Proceedings of the Royal Irish Academy, 107B, 2, 87-94.

De Nie H.W., 1982. A note on the significance of larger bivalve molluscs (Anodonta spp. and Dreissena sp.) in the food of the eel (Anguilla anguilla) in Tjeukemeer. Hydrobiol., 95, 307-310.

De Nie H.W., 1987. Food, feeding periodicity and consumption of the eel Anguilla anguilla (L.) in the shallow eutrophic Tjeukemeer (The Netherlands). Arch. Hydrobiol., 109, 3, 421-443.

Hussein S.A., 1981. The population density, growth and food of eels Anguilla anguilla L. in some tributaires of the river Tweed, Proceedings 2nd Britain Freshwater Fisheries Conference, pp. 120-128.

Lara M.J., 1994. Feeding of eels (Anguilla anguilla L.) in the Narcea basin (Asturias, NW Spain), EIFAC Working Party on Eel, Oviedo, Spain.

Lecomte-Finiger R., 1983. Régime alimentaire des civelles et anguillettes (Anguilla anguilla) dans trois étangs saumâtres du Roussillon. Bull. Ecol., 14, 297-306.

Lobón-Cerviá J. and Rincón P.A., 1998. Field assessment of the influence of temperature on growth rate in a brown trout population. Trans. Amer. Fish. Soc., 127, 718-728.

Lobón-Cerviá J., Utrilla C.G. and Rincón P.A., 1995. Variations in the population dynamics of the European eel Anguilla anguilla (L.) along the course of a Cantabrian river. Ecol. Freshw. Fish, 4, $17-27$.

Moriarty C., 1982. Experiences in eel management in Europe. In: Proceeding 1980' North American Eel Conference. Ontario Technical Reporting Series, 4, 56-65.

Moriarty C., 1987. The eel in Ireland, Royal Dublin Society, Occasional Papers in Irish Science and Technology, $n^{\circ} 4,9 \mathrm{p}$.

Neveu A., 1981. Variations saisonnières et journalières de l'alimentation de l'anguille (Anguilla anguilla L.) dans des conditions naturelles. Acta Oecol. - Oecol. Applic., 2, 2, 99-116.

Rasmussen G. and Therkildsen B., 1979. Food, growth, and production of Anguilla anguilla L. in a small Danish stream. Rapp. P.-v. Réun. Cons. Int. Explor. Mer, 174, 32-40.

Rincón P.A., 1993. Utilización integrada de diferentes recursos: patrones en la alimentación y el uso del microhabitat de una población de Trucha común (Salmo trutta L.) en el Río Negro (Asturias), Tesis Doctoral, Departamento de Biologia Animal I, Facultad de Ciencias Biológicas, Universidad Complutense de Madrid, Spain, 179 p. 
Rincón P.A. and Lobón-Cerviá J., 1997. Temporal patterns in macroinvertebrate drift in a northern Spanish stream. Mar. Freshwater Res., 48, 455-64.

Sinha V.R.P., 1969. A note on the feeding of larger eels Anguilla anguilla (L.). J. Fish Biol., 1, $279-283$.

Sinha V.R.P. and Jones J.W., 1967. On the food of freshwater eels and their relationship with the salmonids. J. Zool., 150, 371-385.

Tesch F.W., 2003. The Eel, 5th Edition, Blackwell Science, Oxford, 434 p.

Thomas J.D., 1962. The food and growth of brown trout (Salmo trutta L.) and its feeding relationship with the salmon parr (Salmo salar L.) and the eels (Anguilla anguilla L.) in the River Teify, West Wales. J. Anim. Ecol. , 31, 175-205.

Utrilla C.G., 1997. Desarrollo y uso de recursos en los juveniles de Salmón atlantico (Salmo salar L.): interacciones entre la estrategia de vida adoptada y el comportamiento exhibido, Tesis Doctoral, Departamento de Biología Animal I, Facultad de Biología, Universidad Complutense de Madrid, Spain, $190 \mathrm{p}$.

Vøllestad L., 1986. Growth and production of female yellow eels (Anguilla anguilla L.) from brackish water in Norway. Vie Millieu, 34, 267-271.

Vøllestad L.A., 1992. Geographic variation in age and length at metamorphosis of maturing European eel: environmental effects and phenotypic plasticity. J. Anim. Ecol., 61, 41-48.

Zar J.H., 1999. Biostatistical Analysis, 4th Edition, Prentice-Hall Inc., Upper Saddle River, USA, 620 p. 